\title{
Marta Kołodziejczyk
}

Uniwersytet im. Adama Mickiewicza w Poznaniu (doktorantka)

\section{Znajomość frazeologii regionalnej wśród poznaniaków}

Polszczyzna mówiona Poznania została do tej pory opracowana dość szczegółowo, prawdopodobnie najlepiej ze wszystkich odmian miejskich ję$z \mathrm{zka}^{1}$. Występującym w poznańskiej gwarze frazeologizmom dotychczas nie poświęcono jednak zbyt dużo uwagi ${ }^{2}$. Jedynym teoretycznym opracowaniem, w którym spróbowano zdefiniować regionalną frazeologię, jest praca Stanisława Bąby i Anny Piotrowicz ${ }^{3}$, powstała na marginesie badań nad słownikiem gwary miejskiej Poznania. Na własny użytek autorzy skonstruowali następującą definicję:

[...] frazeologizmy regionalne - to takie wyrażenia, zwroty i frazy (w tym również przysłowia) spoza współczesnego języka ogólnopolskiego, które powszechnie

${ }^{1}$ A. Piotrowicz, B. Walczak, M. Witaszek-Samborska, Stan i perspektywy badań nad polszczyznq miejska Poznania, w: Miasto. Przestrzeń zróżnicowana językowo, kulturowo i społecznie, red. M. Święcicka, Bydgoszcz 2006, s. 111.

2 Zazwyczaj zajmowano się frazeologią przy okazji badań nad leksyką. Por. A. Piotrowicz, Frazeologia regionalna w twórczości pisarzy wielkopolskich, w: Gwary w Nowotomyskiem na tle gwar zachodniej Wielkopolski, Nowy Tomyśl 1993, s. 26-41; A. Piotrowicz, Funkcje leksyki i frazeologii regionalnej we wspótczesnej prozie (na przykładzie twórczości pisarzy poznańskich), „Poradnik Językowy” 1990, z. 5, s. 337-346; A. Piotrowicz, M. Witaszek-Samborska, Frazeologia regionalna w języku poznańskiej młodzieży, Poznańskie Spotkania Językoznawcze, t. 11, Poznań 2003, s. 89-95; A. Piotrowicz, M. Witaszek-Samborska, Poznańskie stownictwo i frazeologia zwiqzane z komunikacja językowq, w: Studia Językoznawcze. Synchroniczne i diachroniczne aspekty badań polszczyzny, t. 2, red. M. Białoskórska, Szczecin 2003, s. 245-252.

${ }^{3}$ S. Bąba, A. Piotrowicz, Poznańska frazeologia regionalna, w: Synchroniczne i diachroniczne aspekty badań polszczyzny, t. 1, Materiały II Kolokwium Językoznawczego, Szczecin, 16-18 września 1992 r., red. M. Białoskórska, S. Kania, Szczecin 1994, s. 111-122. 
znane są w danym regionie, także inteligencji, przy czym zasięg ich występowania nie zawsze musi być ograniczony do jednego tylko regionu ${ }^{4}$.

Zasoby frazeologiczne gwar i regionalnych odmian języka są skromne i znacznie mniej w nich odrębności niż w zasobach leksykalnych5 ${ }^{5}$. Po porównaniu poznańskich frazeologizmów regionalnych z frazeologią ogólnopolską wyodrębniono trzy grupy ${ }^{6}$ :

1) frazeologizmy semantycznie tożsame $z$ ogólnopolskimi, lecz o nieco zmienionym składzie leksykalnym (co najmniej jeden składnik):

a) z komponentem regionalnym, np. dostać po sznupie - dostać po gębie;

b) z komponentem niebędącym regionalnym odpowiednikiem wymienianego składnika, np. chłop nie ramiqczko - chłop nie ułomek;

2) frazeologizmy nieznane polszczyźnie ogólnopolskiej:

a) zawierające regionalizm leksykalny, np. kupa lumpów, a szczuna ni $m a$ - określenie chudzielca;

b) niezawierające regionalizmu leksykalnego, np. polski urlop 'w wojsku: urlop bez zezwolenia';

c) utrwalone w postaci fonetycznej zgodnej z gwarową wymową wielkopolską, np. żdżarty gatunek 'lakomczuch, żarłok';

3) frazeologizmy nawiązujące do niemieckich konstrukcji składniowych i frazeologicznych, np. być wyjechanym precz 'wyjechać dokądś' (niem. verreist gewesen sein).

Badacze zauważyli, że poszczególne warstwy różnią się pod względem ilościowym - największą grupę tworzą frazeologizmy nieznane polszczyźnie ogólnopolskiej. Najmniej liczne są kalki i parafrazy z języka niemieckiego. Stanowią elementy recesywne, wychodzące najszybciej z użycia, tak jak germanizmy leksykalne.

Przedmiotem moich rozważań jest stopień znajomości frazeologii regionalnej wśród współczesnych użytkowników gwary miejskiej Poznania w odniesieniu do ich wieku oraz struktury genetycznej związków. W celach badawczych została skonstruowana ankieta. Podstawowe źródło ekscerpcji badanych związków wyrazowych stanowił Stownik gwary miejskiej Poznania ${ }^{7}$. Zaczerpnięto z niego 501 frazeologizmów. Następnie wyeliminowano te połączenia wyrazowe, które przeniknęły już do odmiany potocznej języka ogólnego. $\mathrm{Na}$

\footnotetext{
${ }^{4}$ Ibidem, s. 112.
}

${ }^{5}$ Por. Frazeologia gwarowa [hasło], w: Encyklopedia języka polskiego, red. S. Urbańczyk, M. Kucała, wyd. 3 popr. i uzup., Wrocław 1999, s. 104.

${ }^{6}$ S. Bąba, A. Piotrowicz, op.cit., s. 113-116.

7 Stownik gwary miejskiej Poznania, red. M. Gruchmanowa, B. Walczak, wyd. 2, Warszawa-Poznań 1999. W dalszej części pracy posługuję się skrótem SGMP. 
podstawie najnowszych słowników polszczyzny potocznej ${ }^{8}$ można stwierdzić, że poniższe jednostki straciły status regionalizmów: być na fleku, być po jednych pieniqdzach, chichrać sie jak gtupi do sera, dostać // dostawać szmergla, insza inszość, mieć (coś) z deklem, mieć (coś) z gorem ${ }^{9}$, mieć fefry, mieć nierówno pod sufitem, mieć szmergla, na krychę $e^{10}$, na zaś, nie mieć wszystkich $w$ domu, robić komuś koło dupy, robić w pory, robić za kogoś, rypać prawdę prosto w oczy, rżnać kogo (gtupa), srać w pory, trzaśść porami ze strachu, trzymać pysk, w życiu.

Ze względu na obszerność materiału, utrudniającą skuteczne przeprowadzenie badań, wykluczono również te związki frazeologiczne, które oznaczono w SGMP kwalifikatorami dawny oraz przestarzały. Były to w znacznej części wyrażenia i zwroty odnoszące się do czasów minionych (przed- i powojennych), w dzisiejszych realiach niemające już zastosowania ${ }^{11}$. Mam tu na myśli takie połączenia wyrazowe, jak m.in.: bamberski strój 'strój przypisany kolonistom niemieckim przybyłym w drugiej połowie XVIII wieku z Bambergu do podmiejskich wsi Poznania', ciepłe kraje 'tereny spoza dawnego zaboru pruskiego, z których przybysze osiedlali się po roku 1920 w Wielkopolsce', ciotka Unrra 'potoczna nazwa UNRRA - Organizacji Narodów Zjednoczonych do Spraw Pomocy i Odbudowy', czarna ksiazka 'obowiązkowy w dwudziestoleciu międzywojennym dokument prostytutki w rodzaju książeczki zdrowia z wpisanymi datami badań kontrolnych', grać $w$ depoki 'grać w guziki', grać w syra 'zabawa dziecięca rozpowszechniona tuż po wojnie [przy użyciu cegieł i kamieni - M.S.]', gra w bejmy 'gra w monety', kapa złotolita 'nakrycie głowy w stroju Bamberki', Kaczmarek-regimenty 'formacje w wojsku pruskim składające się z Wielkopolan', mieć czysta bieliznę 'należeć do związku zawodowego', szewskie spodnie 'element ubioru Bambra', sztywne piersi 'krochmalony gors koszuli', szwadronowe trzewiki 'element stroju Bamberki', teatr świetlny 'kino', warciane dzieci 'dzieci objęte działalnością założonego w maju 1894 roku przez Anielę Tułodziecką Towarzystwa „Warta"', zefirowy fartuch 'element stroju Bamberki', zielony wujek 'magistracki porządkowy, usuwający drobne śmieci w mieście'.

8 J. Anusiewicz, J. Skawiński, Słownik polszczyzny potocznej, wyd. 2 popr., Warszawa 1998; M. Czeszewski, Słownik polszczyzny potocznej, Warszawa 2006; Słownik polskich leksemów potocznych, red. W. Lubaś, t. 1-4, Kraków 2001-2006. Dotychczasowe tomy obejmują litery A-L, toteż analiza ta może być niepełna.

9 Słownik notuje związek w postaci mieć (coś) z garem, ale zachodzi tu jedynie oboczność fonetyczna.

${ }_{10}$ Podobnie jak w powyższym przypadku - w słowniku zanotowano oboczną formę na krechę.

11 Nie wszystkie z nich zostały opatrzone wymienionymi kwalifikatorami. 
Ostatecznie w ankiecie znalazło się 425 frazeologizmów pochodzących ze słownika. Dodatkowo umieszczono w niej 14 wyrażeń i zwrotów gwarowych niezanotowanych w SGMP, lecz znanych autorce pracy ${ }^{12}$.

Początkowym założeniem było objęcie badaniami co najmniej 200 respondentów. Jednak z uwagi na trudności ze znalezieniem osób chętnych do wypełnienia ankiety o tak sporych rozmiarach ograniczono ich liczbę do 120. Wiek ankietowanych mieścił się w przedziale 15-87 lat. Wydzielono trzy grupy wiekowe: najmłodszą (poniżej 30 lat), średnią (31-59 lat) i najstarszą (powyżej 60 lat) ${ }^{13}$. Starano się, aby poszczególne pokolenia reprezentowane były przez podobny procent badanych. Ostatecznie jednak proporcje są nieco zachwiane - grupy liczą odpowiednio: 52, 41 i 27 respondentów.

Warunek niezbędny do wzięcia udziału w badaniu to pochodzenie. Uczestniczyli w nim głównie rodowici poznaniacy lub osoby wywodzące się z terenu Wielkopolski (urodzone poza Poznaniem), lecz mieszkające w mieście od dłuższego czasu (minimum 20 lat w przypadku pokoleń średniego i najstarszego, minimum 10 lat w najmłodszej grupie). Nieliczne są osoby pochodzące z innych części kraju (tylko w starszych pokoleniach) - zamieszkałe w Poznaniu od minimum 30 lat. Ankietowani reprezentują różny poziom wykształcenia (podstawowe, średnie, zawodowe, wyższe), a także różne zawody.

Pytania zadane użytkownikom gwary poznańskiej, zamieszczone w tabeli z zebranymi związkami frazeologicznymi, brzmiały: „Czy znasz?”, „Czy używasz?” oraz „Co to znaczy?”. Analizie miały zostać poddane odpowiedzi na pytanie pierwsze - czyli świadczące o biernej znajomości frazeologii przez respondentów - oraz odpowiedzi na pytanie drugie - poświadczające znajomość czynną podanych związków ${ }^{14}$. W obu sytuacjach niezbędnym wymogiem było podanie poprawnej definicji związku. Z racji tego, iż jedynie w niektórych ankietach zastosowano się do prośby o oznaczenie formy znanej przez respondenta, w pracy nie będzie rozpatrywane zróżnicowanie znajomości wariantów frazeologicznych (np. być żent // żynt // dżynt), choć był to również jeden z zakładanych celów tych badań.

$\mathrm{Na}$ podstawie zebranego materiału można stwierdzić, że znajomość poszczególnych frazeologizmów jest bardzo zróżnicowana, nie tylko ze względu na wiek respondentów. Istnieje duża grupa związków, których frekwencja jest

${ }^{12}$ Są to: ćpane kluski, haknij mnie w nyry, mieć na coś dlugie zęby, my i oni na zabawie u nich, na feste, o jaśnie, prawo haja, raz przy razie, sierota otabaczona, stodki pamper, szare kluski, świgać kurwami, takiej kundzie (jak ty) to ujdzie, za chachot.

${ }^{13}$ Dla ułatwienia w dalszej części pracy korzystam z nazw pokolenie I (młode), II (średnie), III (starsze).

${ }^{14}$ Sformułowanie „znajomość bierna” oznacza tu, że respondent zna związek wyrazowy, ale go nie używa, zaś „znajomość czynna” - że frazeologizm występuje w wypowiedziach danego respondenta. 
bardzo wysoka we wszystkich grupach. Niektóre zaś wycofują się z komunikacji werbalnej do tego stopnia, iż nie rozumieją ich nawet najstarsi poznaniacy. Średnia znajomość bierna frazeologizmów wynosi ${ }^{15}$ : w pokoleniu I - 50, w pokoleniu II - 124, w pokoleniu III - 142. Jeśli chodzi o znajomość czynną, sytuacja wygląda znacznie gorzej. Mimo że większość respondentów świetnie orientuje się w zasobach frazeologii regionalnej, nie sięgają do niej zbyt często (a przynajmniej tak deklarują). Średnia znajomość czynna wynosi: w pokoleniu I - 16, w pokoleniu II - 32, w pokoleniu III - 25. Dziesięć najczęściej używanych frazeologizmów to ${ }^{16}$ : na szage 'na ukos, na przełaj' ${ }^{17}$ (36\%), babskie pierdoty 'babskie gadanie' (35\%), iść (robić) nyny 'iść spać' (29\%), robić // zrobić łóżko, tapczan 'słać łóżko, tapczan itp.' (29\%), być bejt 'być wykończonym, skrajnie zmęczonym, osłabionym' (28\%), drzeć kalafę 'krzyczeć, wrzeszczeć' (28\%), modra kapusta 'czerwona kapusta' (28\%), mieć wypite 'być pod wpływem alkoholu' (28\%), brać // wziać giry za pas 'uciekać' (27\%), dostać na głowę 'dostać bzika, zwariować' (27\%). W poszczególnych pokoleniach zestaw ten nieznacznie się zmienia pod względem frekwencji, czasami następuje wymiana frazeologizmów.

Łatwo zauważyć, że najpopularniejsze związki frazeologiczne przyporządkować można do pewnych pól semantycznych:

a) codzienne czynności: być u roboty 'być w pracy', iść (robić) nyny, robić // zrobić łóżko, tapczan, wkulnać się do łóżka 'położyć się do łóżka', wśród nich zwłaszcza nazwy związane z pożywieniem i konsumpcją: modra kapusta, na spróbe 'do spróbowania', szneka z glancem 'drożdżówka z lukrem', wpaść do niemieckiej dziurki // w niemieckq dziurke 'wpaść do tchawicy';

b) ludzkie zachowania: babskie pierdoły, bieda się hejbła 'o kimś biednym, kto nieoczekiwanie zdobył się na duży wydatek', brać // wziać giry za pas, dać sobie czas 'nie spieszyć się', drzeć kalafę;

c) określenia cech człowieka (w tym opisujących stan jego umysłu): być bejt, dostać na głowę, mieć rułę 'być opanowanym, spokojnym [powolnym]', mieć wypite, pierdoła z Gaqdek 'gaduła, plotkarz';

d) wykrzyknienia i zwroty emocjonalne: co ja za to moge?? 'cóż ja na to poradzę?', idź w pyry 'idź sobie, idź dokąd chcesz', o co się rozchodzi? 'o co chodzi?', ruk cuk // rug cug // ruck-zuck'szybko, w mig'.

15 Większość wartości liczbowych i procentowych została zaokrąglona do pełnych liczb.

16 Związki podaję w kolejności zgodnej z frekwencją. Przyjęto, że najbardziej znane frazeologizmy to te, których frekwencja wynosi powyżej 55\%, najmniej znane - poniżej $10 \%$. Ponieważ czynna znajomość frazeologii nie przekroczyła 55\%, rozpatruję te związki, których frekwencja wynosi powyżej 10\%.

17 Znaczenia podaję w większości za SGMP, ewentualne poprawki odautorskie umieszczam w nawiasach kwadratowych. 
Młodsi użytkownicy miejskiego języka potocznego korzystają przede wszystkim z frazeologizmów odnoszących się do powszechnych doświadczeń. Możemy do nich zaliczyć, oprócz wcześniej wymienionych, także na piechty // piechtę 'pieszo, na piechotę' (26\% w grupie I) lub na szagę (w znaczeniu 'na przełaj, na skróty'), które odnoszą się do jednej z podstawowych ludzkich czynności, czyli chodzenia. Poza tym ankietowani z grupy I chętnie korzystaja ze zwrotów nacechowanych emocjonalnie, obecnych w gwarze poznańskiej w całkiem sporej liczbie. Mam tu na myśli ekspresywne określenia, których celem jest wyrażenie negatywnej oceny osoby (lub jej zachowania czy związanego z tym stanu umysłu) bądź nazwanie czynności związanych z używaniem siły fizycznej (np. znaczenia: 'ktoś zwariował, ma głupie pomysły, dziwnie się zachowuje', 'odejdź, odczep się, przestań wygadywać bzdury', 'uderzyć kogoś', 'dostać lanie' itp.). W pokoleniu I oprócz popularnego powszechnie dostać na glowę $e^{18}$ (tu: $30 \%$ ) często występuje zwrot $i d z$ ź pyry (używany przez nielicznych starszych - 7\% i 3\% w grupach II i III, 28\% w grupie I). Inne, rzadsze przykłady to: powyrywać komu giry z tyłka // z dupy 'grozić komu dotkliwym pobiciem, zmaltretowaniem' (23\%), dostać po sznupie 'dostać po gębie' (21\%), mieć szajbę 'mieć bzika, zachowywać się anormalnie' (19\%). Z kolei pytanie o co się rozchodzi? (26\%) stanowi zapewne wyraz pragnienia bycia ze wszystkim na bieżąco (szczególnie z wydarzeniami towarzyskimi) sądzę, że właśnie ta grupa najbardziej takie chęci przejawia. Jedyną szerzej używaną w pokoleniu I nazwą związaną z jedzeniem jest szneka z glancem $(26 \%)$. W sumie liczba frazeologizmów używanych w tym przedziale wiekowym waha się od 0 do 102 .

Pokolenie średnie najczęściej korzysta z regionalnej frazeologii. Najlepszym dowodem na to jest najwyższa ze wszystkich grup frekwencja używania $-48 \%$ - związków frazeologicznych: modra kapusta oraz być bejt. W tym pokoleniu wśród połączeń wyrazowych wymienionych jako stosowane nieco odmiennie pod względem znaczeniowym od wcześniej omawianych jest pytanie co ja za to mogę? (39\%), które sugerować może postawę bezsilności. Oprócz tego w grupie II pojawiają się także frazeologizmy odnoszące się do codziennych czynności: pracy (być u roboty - 29\%) i konsumpcji (czy raczej zjawisk z nią powiązanych: na spróbe - 34\%, wpaść do niemieckiej dziurki // w niemiecka dziurke -29\%) oraz ironiczne określenie mieć rute (29\%), często stosowane w odniesieniu do czyjegoś zachowania. Ogólna liczba związków używanych przez pokolenie II - od 0 do 224.

${ }^{18}$ O popularności tego związku może świadczyć fakt, iż często za jego pomocą definiowano inne frazeologizmy o tym samym znaczeniu. 
Grupa najstarsza używa najczęściej, prócz omówionych wcześniej związków ogólnie popularnych, także frazeologizmów mniej znanych młodszym respondentom, np. bieda się hejbła (tu: $33 \%$, niecałe $2 \% \mathrm{w}$ grupie I), dać sobie czas (tu: 22\%, 5\% w grupie I), pierdoła z Gadek (tu: 22\%, niecałe 2\% w grupie I i 7\% w grupie II), ruk cuk // rug cug // ruck-zuck (tu: 22\%, 5\% w grupie I). Frazeologizmem popularnym wśród respondentów najstarszych jest również wkulnać się do tóżka (tu: $22 \%$, frekwencja w pozostałych grupach też dość wysoka: 19\% w grupie I, 21\% w grupie II). Stosowany jest on najczęściej w kontaktach z dziećmi. W przeciwieństwie do grupy najmłodszej pokolenie III używa mało wyrażeń i zwrotów nacechowanych emocjonalnie (szczególnie negatywnych). Najmniejsza znajomość czynna regionalnej frazeologii w tej grupie respondentów to 0, największa - 149 .

Odnosząc się do wspomnianego na wstępie podziału regionalnych frazeologizmów na trzy grupy genetyczne, przyporządkowałam do nich wszystkie badane związki, a następnie porównałam ich obecność w języku poszczególnych pokoleń.

\section{Frazeologizmy semantycznie tożsame z ogólnopolskimi}

Odpowiedników związków ogólnopolskich jest 135, w tym 120 z komponentem regionalnym. Wśród dziesięciu najpopularniejszych frazeologizmów znalazło się aż pięć z omawianej grupy (babskie pierdoły, brać // wziać giry za pas, drzeć kalafę, modra kapusta, na szage). Oprócz nich frekwencję powyżej $10 \%$ miały związki ${ }^{19}$ :

- w grupie I: na piechty // piechtę, o co się rozchodzi?, szneka z glancem (26\%), powyrywać komu giry z tyłka // z dupy (23\%), dostać po sznupie (21\%), drzeć sie jak stare pory 'krzyczeć, wrzeszczeć', kielczyć sie jak (głupi) do syra 'głupio się śmiać', na spróbe (19\%), mamrotać pod kluka 'mówić cicho, niewyraźnie', o ciemku // ciymku 'po ciemku', robić sobie szyderę z kogo 'kpić z kogo' (15\%), być u roboty, dzięka Bogu 'dzięki Bogu', spuścić tynt // tynty // tęt // luńty 'zbić kogo', żyć na kryche 'żyć z kimś bez ślubu' lub ‘żyć na kredyt' (13\%), dostać w glace 'oberwać, dostać po głowie', trochę bejma 'trochę pieniędzy', walić w pory 'trząść się ze strachu' (11\%);

- w grupie II: na spróbe (34\%), być u roboty (29\%), dostać po sznupie, szneka z glancem (26\%), amba komu odbija 'ktoś wariuje', dać sznupki 'dać buzi’ (24\%), kielczyć się jak (głupi) do syra, żyć na kryche (21\%), chcesz w glacę? 'pogróżka: chcesz oberwać?', dostać w glacę, mamrotać pod kluka, na ula (fif) 'byle jak, na niby', wygladać jak trup // śmierć na urlopie 'wyglądać mizernie, źle' (19\%), bez most 'przez most', dostać po kluce // w kluke

19 Kolejność ze względu na frekwencję, związki pogrupowane według tej samej wartości procentowej umieszczonej na końcu danej grupy. 
'zostać uderzonym w nos' lub 'dostać nauczkę', dzięka Bogu, robić szneke 'robić minę' (17\%), dać kepe 'dać nurka', dać sobie w tyte 'upić się', drzeć się jak stare pory, mieć fifa 'mieć talent, szczególną umiejętność', po ździeb$k u$ 'po trochu - w małych dawkach, stopniowo', z dęba spadteś? 'wyrażenie zdumienia wobec czegoś zaskakującego', zamknać kalafe 'milczeć, milknąć' (14\%), artycha ze spalonego teatru 'lichy artysta', chłop nie ramiaszko // ramiqczko 'określenie postawnego mężczyzny', dostać gila 'zwariować', dostać bynt // tynty 'dostać lanie', głupoty się komu trzymaja // trzymały 'żarty się kogo trzymają', mówić krótko i zwięzłowato 'mówić zwięźle', na doczekaniu 'na poczekaniu', na obatke // obołke 'na okrętkę', o ciemku // ciymku, pyry deptane 'ziemniaki puree', robić sobie szydere z kogo, stary śrup 'stary pryk', szkoden goden 'niby po niemiecku: szkoda gadać', świgać kurwami 'przeklinać', wedle mnie 'moim zdaniem', wyszło // wylazło szydło z miecha 'wyszło szydło z worka’ (12\%);

- w grupie III: być u roboty (25\%), kielczyć się jak (głupi) do syra, po ździebku, rosnać jak na młodziach 'rosnąć bardzo szybko', szneka z glancem, żyć na kryche (18\%), amba komu odbija, dostać po sznupie, mieć kalafe od ucha do ucha 'być pyskatym, kłótliwym', na piechty // piechtę, na spróbe, robić sobie szydere z kogo, stulić kalafe 'zamilknąć, zamknąć się', szkoden goden, zamalować w kalafę 'uderzyć w twarz', zbijać kapuchę 'zbijać majątek' (14\%), artycha ze spalonego teatru, bez most, dać sznupki, dostać gila, dostać po kluce // w klukę, dostać w glacę, gtupoty się komu trzymaja // trzymały, kupić kota w miechu 'kupić coś bez sprawdzania, bez obejrzenia', mieć fifa, mieć gila 'mieć bzika', mówić krótko i zwięzłowato, na doczekaniu, pyry deptane, stary śrup, stroić sobie ubaw 'stroić sobie żarty', śrupy można z kim kraść 'można mieć do kogo zaufanie', trochę bejma, trzymać kalafe 'milczeć', wtykać // wetknać kluke w co 'zaglądać do czego' lub 'interesować się czym, wtrącać się do nie swoich rzeczy', wyciagnać szwaje 'umrzeć', wyćpić kogo na łeb 'wyrzucić kogo, wypędzić', wygladać jak trup // śmierć na urlopie, wystworzać faksy 'stroić figle', zadzierać kluke 'zadzierać nosa, wynosić się nad innych, być dumnym', zalakierować w kalafe 'uderzyć w twarz', zalakierować w papę 'uderzyć w twarz' (11\%).

Zaledwie 15 związków (czyli 11\% grupy frazeologizmów semantycznie tożsamych z ogólnopolskimi) miało frekwencję zerową (znajomość czynna): bubek żołędny 'oferma', być nałożonym do pracy 'być wprawionym w wykonywaniu czegoś', głabnać szplina 'dostać fioła', idź mi w kibinimać! 'uciekaj, odczep się', mieć drajera 'mieć bzika, zwariować', mieć powiedziane // powiedzone 'mieć przykazane', mieć $w$ modzie 'mieć w zwyczaju', prawo haja 'prawo pięści', puszczać // puścić mare 'puścić bąka', stuknij się w katę! 'puknij się w czoło', świat się lyro 'świat się wali', z winkla 'z ukosa', za dość 'za 
dużo'. W tym dwa są w ogóle nieznane: zażyć kogoś od Bukowskiej 'okpić kogoś', na durch 'na przełaj, najkrótszą drogą, na wprost'.

Wśród najbardziej znanych związków (znajomość bierna) 67\% to frazeologizmy mające swój ogólnopolski odpowiednik.

\section{Frazeologizmy rodzime nieznane polszczyźnie ogólnopolskiej}

Najliczniejsza grupa to frazeologizmy nieznane odmianie ogólnej języka: łącznie 259 , czyli prawie $60 \%{ }^{20}$. Nie są one jednak tak popularne jak grupa poprzednia. Wśród najczęściej używanych znajdują się cztery: być bejt, dostać na głowe, iść (robić) nyny, mieć wypite. Inne związki o frekwencji powyżej $10 \%$ to:

- w grupie I: idź $w$ pyry (28\%), robić nyny 'spać' (23\%), dostać wilka 'przeziębić się od siadania na zimnym kamieniu, ziemi', wlewać sobie // se 'wynosić się ponad innych, być zarozumiałym' (21\%), wkulnqć się do tóżka $(19 \%)$, mieć nierówno poukładane 'być nie w pełni władz umysłowych' (17\%), mieć w porach ze strachu 'o człowieku płochliwym' (15\%), co chciatem powiedzieć, (a) nie skłamać... 'fraza wypowiadana w momencie, gdy mówiący usiłuje sobie przypomnieć, co przed chwilą chciał powiedzieć', swoja wiara 'ludzie podobni do nas, w których towarzystwie dobrze się czujemy' (13\%), co po chwitke // co pofile // co po chwila 'co chwilę', marciński // świętomarciński rogal 'rogal nadziewany masą z białego maku i migdałów, wypiekany w dniu św. Marcina - 11 listopada', może mi skoczyć na wacka! 'nic mi nie może zrobić', nabrechtać sobie 'przysporzyć sobie kłopotów, strat', poznańska pyra 'prawdziwy poznaniak', szare kluski 'kluski z tartych surowych ziemniaków z mąką, zazwyczaj podawane z przysmażoną cebulką lub ze skwarkami' (11\%);

- w grupie II: wpaść do niemieckiej dziurki // w niemiecka dziurkę (29\%), idź do boru (na bedki)! 'odczep się! zostaw mnie w spokoju' lub 'nie gadaj głupstw!', mieć na coś dtugie zęby 'nie mieć na coś apetytu, nie lubić czegoś (jedzenia)', szare kluski (26\%), ino (mi) ciag! 'daj mi spokój, odczep się', ino pędź // pyńdż 'zmykaj, odczep się, daj spokój', marciński // świętomarciński rogal (24\%), wkulnać się do tóżka (21\%), ciag drut 'idź sobie', dostać wilka, robić nyny, słodki pamper 'osoba lubiąca słodycze', trzy światy 'wielkie kłopoty, zamieszanie itp.' lub 'uciecha, zabawa' (19\%), bieda się hejbła, co chciatem powiedzieć, (a) nie skłamać..., dostać fefrów 'wystraszyć się', nabrechtać sobie, wlewać sobie // se (17\%), Boże rany (od deski do ściany) 'rytualno-zabawowe bicie dzieci w Wielki Piątek rano, często towarzyszyły temu tego typu rymowanki', dostać gis 'zmoknąć solidnie', iść // chodzić na

${ }^{20}$ Nie licząc związku mieć ptoka, który będąc zwrotem utrwalonym w postaci fonetycznej zgodnej z gwarową wymową wielkopolską, równocześnie należy do frazeologizmów pochodzenia niemieckiego (i został do nich wliczony). 
fusiere 'wykonywać dodatkową pracę, poza godzinami obowiązującymi', $\mathrm{ka}$ lafa się komu drze 'spać się komu chce, ktoś ziewa', klak albo wetna, byle dupa petna 'nieważne, co się je, byle się najeść', kupa lumpów, a szczuna nie ma, swoja wiara, ślepe ryby (z myrdyrda) 'zupa ziemniaczana', żdżarty gatunek 'żarłok' (14\%), być na ostatnich girach 'być w zaawansowanej ciąży', cholera // kurczę nie dzie // gdzie 'formuła przekleństwa', ciagnać okowite 'pić spirytus lub denaturat', czarcie żebro // ziele 'ziele ostrożenia, zioło o cudownej mocy', dać sobie czas, dalas w kieszeni 'bycie biednym, brak pieniędzy', elegant z Mosiny 'o kimś ubranym pretensjonalnie, bez smaku', idzie // szło na gisówkę // gisówe 'zanosi się na deszcz', jak na chlyb będziesz mówić byb, a na muchy ptapty 'gdy będziesz już stary i niedołężny', kusić po nocach 'zajmować się czym w nocy', mieć naćpane 'mieć źle w głowie, być głupim', mieć nierówno poukładane, na Boże rany bija barany 'rymowanka towarzysząca biciu dzieci w Wielki Piątek', na cycuś 'wyjątkowo starannie, bardzo dobrze', poznańska pyra, poznańska wiara 'poznaniacy', wysieknięty // odstrzelony jak do (t)ośpic 'wystrojony', za chachot 'za ubranie (na karku), za kołnierz (np. chwycić)' (12\%);

- w grupie III: bieda się hejbła (33\%), dać sobie czas, pierdoła z Gadek, wkulnać się do tóżka (22\%), dalas w kieszeni, dobra kawa 'kawa naturalna', na cycuś, robić nyny, swoja wiara, szare kluski, wefte $i$ wefte // ftefte 'tam i z powrotem', żdżarty gatunek (18\%), Bambrejewo, powiat Gacie, województwo Kalesony 'zapadła wieś', czarcie żebro // ziele, dać w skok 'uciec', dostać fefrów, dostać wilka, dusić garę 'spać', kawa ze stodoły 'kawa zbożowa', kupa lumpów, a szczuna nie ma, mieć na coś dtugie zęby, mieć rachę na kogo 'długo gniewać się na kogo, chować w sercu urazę', o jaśnie 'rano, za dnia (przy dziennym świetle)', same pory chodza 'określenie chudej osoby', wpaść do niemieckiej dziurki // w niemieckq dziurkę, zimne nogi // nóżki 'galareta z nóg wieprzowych lub wołowych' (14\%), Boże rany (od deski do ściany), być na ostatnich girach, być żent // żynt // dżynt 'być dżentelmenem', ciag drut, ciqgnać okowite, idź (lots) z tym koksem! 'odczep się', iść // chodzić na fusiere, marciński // świętomarciński rogal, melić papq 'mówić szybko, bezładnie', mieć galare w porach 'bać się', mieć gzik w kolanach // w girach 'odczuwać słabość i drżenie nóg na skutek silnego zmęczenia lub przestrachu', mieć naćpane, mieć nierówno poukładane, mieć ptapty 'zachowywać się infantylnie, być niedorozwiniętym umysłowo', nośpłata syn 'o kimś zabiedzonym, kto wygląda jak siódme dziecko stróża', opękać biedę 'przetrwać trudny okres', poznańska babka 'babka piaskowa', poznańska pyra, robić na bimbie 'pracować jako motorniczy', rozewrzeć kalafe 'zacząć krzyczeć, wrzeszczeć', rozpuścić kalafe 'krzyczeć, wrzeszczeć', roztworzyć pape 'zacząć mówić, krzyczeć', siedzieć komu na kicie 'jechać za kimś w bardzo małej odległości’, słodki pam- 
per, sprawić sobie tyte 'upić się', wielkopolska pyra 'prawdziwy poznaniak', wlewać sobie // se, wysieknięty // odstrzelony jak do (t)ośpic, wytośtać kogo za kłaki 'wytargać kogo za włosy', zez tyndy do tamtyndy 'stąd dotąd' (11\%).

Zerową frekwencję miały następujące związki: bity Polak 'zagorzały Polak', boża męka 'przydrożny krzyż, figura, kapliczka', brać ślub pod dzika grusza 'żyć bez ślubu', co ino 'dopiero co', góli oka 'dla pozoru', idź w kieretyny! 'odczep się, nie mów głupstw', kampa góra! 'termin z gry w palanta', klepane jaja 'rodzaj jajecznicy z mąką i mlekiem', latać po psich zbyrach 'zbijać bakki', lepsza nuta 'prostytutka', leżé jak plyndz na patelni 'o sytuacji bez wyjścia', mieć coś (na) wizawis 'mieć co przeciw czemu', mieć myk-myk 'być upośledzonym umysłowo, nienormalnym', mieć naćpane, ale nie pomieszane 'mieć źle w głowie, być głupim', mieć nadrzuzgane 'być zbitym, pobitym', mieć nagibane 'być nienormalnym, chorym umysłowo', mieć narżnięte 'być pobitym, zbitym' lub 'wypróżnić się, zrobić kupę, mieć naświgane 'być głupim, nienormalnym', mieć pyszczek jak toruszke 'mieć twarz bardzo szczupłą albo pomarszczoną, na cołki łeb 'całkowicie', na jeden hib 'za jednym razem', na odsiebkę // odsiybke 'w przeciwną stronę, w lewo', najadła się stara baba torków $i$ beble 'o kimś, kto mówi od rzeczy', narżnać na co 'mieć co w nosie, być obojętnym na co', nie ma musu ni pana 'nie jest konieczne', papudrak z ciepłych krajów 'obcy, przybysz', radio Swarzędz 'radio Wolna Europa', sratus // stratus gównatus 'figa z makiem', sroł grot 'negatywna ocena czyjegoś zachowania lub wypowiedzi', stwarzać // stworzyć sobie 'wymyślać nieprawdopodobne rzeczy', szak nie? // szak tak? 'czyż nie, nieprawdaż?', szport na kiju, parada na widelcu 'ale ubaw', ślepa omaza // obmaza 'byle co, coś bez żadnej wartości', wej sa gó! 'popatrz na niego!', wielka msza 'suma', wypędzić komu muki 'oduczyć dąsów', wziać coś na pierwszy hib 'wziąć coś od razu', z kędykiś 'skądś', za kogo 'jako kto', złokreś, nie gdzie 'wzmocnione przekleństwo', zupa bułczanna 'wywar po bułczance' - w tym nieznane w ogóle respondentom: cacy, cacy - buch po glacy 'żartobliwa rymowanka odnosząca się zwykle do osoby łysej', ciepty land 'Galicja', dać się za kogo 'zostać kim', matka smaż, póki masz 'nie ma co martwić się o przyszłość', nagie kluski 'kluski z surowych ziemniaków z mąką, nie ma da // nima da 'nic do tego', psie zbyry 'próżnowanie, zbijanie bąków', szary bary 'rodzaj ciastek', z miasta 'tak o produktach fabrycznych w przeciwieństwie do wyrobów domowych'. Stanowią one 19\% wszystkich frazeologizmów nieznanych polszczyźnie ogólnej.

Jeśli chodzi o najbardziej znane związki (znajomość bierna), tylko 29\% z nich należy do omówionej właśnie grupy zwrotów i wyrażeń - stanowi to liczbę dwa razy mniejszą niż w przypadku grupy frazeologizmów semantycznie tożsamych z ogólnopolskimi. 


\section{Kalki i parafrazy pochodzenia niemieckiego}

Liczba zapożyczeń frazeologicznych wynosi 45 , co stanowi zaledwie $10 \%$ wszystkich poznańskich spetryfikowanych połączeń wyrazowych. Związki te nie należą do ekspansywnych zasobów gwary miejskiej. Aż 40 frazeologizmów mieści się w grupie wyrażeń i zwrotów rzadko używanych przez ogół respondentów (poniżej 10\% użytkowników). Tylko trzy miały frekwencję zerową: dodać się do czego 'zabrać, przyłożć się do czego', mieć odbite 'mieć głupie pomysły, być zwariowanym, głupim', mieć świnię 'mieć szczęście'.

Najbardziej popularnym związkiem o niemieckim rodowodzie jest robić // zrobić tóżko, tapczan, który znalazł się wśród 10 najczęściej używanych zwrotów (używa go $29 \%$, zna $58 \%$ ankietowanych). Oprócz niego wśród połączeń wyrazowych, które miały ponad $10 \%$ frekwencji znajdują się:

- w grupie I: co ja za to mogę? (21\%), mieć szajbe (19\%);

- w grupie II: co ja za to mogę? (39\%), mieć rułe (29\%), do góry 'na górę, w górę, na górze, w górze', dostać szplina 'zbzikować, zwariować' (19\%), dostać rapla 'dostać bzika', ruk cuk // rug cug // ruck-zuck (17\%), dostać sztycha 'o nieświeżych produktach żywnościowych, nadpsuć się, skwasić się', mieć ambę 'mieć głupie pomysły, być zwariowanym', mieć szajbę (14\%), być precz // prek 'być nieobecnym, odejść', być wyjechanym precz // prek 'wyjechać dokądś', co jest lots? 'o co chodzi? co się dzieje?', dodawać sobie 'wywyższać się', dostać kupić 'kupić, móc kupić' (12\%);

- w grupie III: ruk cuk // rug cug // ruck-zuck (22\%), co ja za to mogę?, mieć gryf 'być zręcznym, mieć uzdolnienia, szczególnie manualne', mieć rutę, mieć sztycha 'być zepsutym, nadpsutym' (14\%), dostać kupić, dostać rapla, mieć muki 'dąsać się', mieć ptoka 'mieć bzika, być głupim', mieć weg 'mieć fioła', stojało // stoi w gazecie 'być napisanym w gazecie' (11\%).

Jeśli chodzi o znajomość bierna, 34 związki frazeologiczne zostały rozpoznane przez więcej niż $10 \%$ respondentów. Żaden nie miał frekwencji zerowej.

Z powyższej analizy regionalnej frazeologii można wyciągnąć następujące wnioski.

1. Liczba użytkowników jest zróżnicowana w zależności od grup wiekowych, ale w nietypowy sposób - wbrew przewidywaniom pokolenie najlepiej znające (czynnie) frazeologizmy gwarowe to nie pokolenie najstarsze, lecz pośrednie ${ }^{21}$. Natomiast znajomość bierna zwrotów i wyrażeń utrzymuje się na niemal równym poziomie w grupach II i III. Nie ulega jednak wątpli-

${ }^{21}$ Wydawałoby się, że skoro czynniki decydujące o kształcie gwary poznańskiej (np. wpływ języka niemieckiego) oddziaływały na nią w przeszłości, to wraz z ustaniem ich działania elementy regionalne powinny pozostać głównie w obrębie języka osób najstarszych. 
wości, że frazeologia ta jest coraz mniej znana ludziom najmłodszym. Inne czynniki, np. poziom wykształcenia, nie wpływają w dużym stopniu na liczbę znanych związków ${ }^{22}$. Wszystko wskazuje jednak na to, że osoby z wykształceniem średnim deklarują większą znajomość czynną, niż osoby z wykształceniem wyższym (co zgadza się z częstym, lecz błędnym mniemaniem, iż gwara miejska to mowa ludzi niewykształconych) ${ }^{23}$.

2. Główne pola semantyczne poznańskich związków frazeologicznych dotyczą człowieka - opisu jego cech oraz zachowań i czynności, przeważnie codziennych i każdemu znanych. Najmłodsi respondenci często używają określeń ekspresywnych, których w gwarze poznańskiej nie brakuje (np. cała seria połączeń z wyrazem kalafa: drzeć kalafę, stulić kalafe, zamknać kalafę itp.).

3. Najbardziej ustabilizowaną grupą są związki frazeologiczne mające odpowiedniki w polszczyźnie ogólnej. Przodują one w zestawieniach najczęściej używanych i najbardziej znanych połączeń wyrazowych. Wynika to zapewne z tego, iż wymiennoczłonowe związki, w których znajduje się element pochodzenia gwarowego, mają zazwyczaj większe nacechowanie emocjonal$n^{24}$. Dosadność i ekspresywność są cechami charakterystycznymi frazeologii potocznej ${ }^{25}$.

4. Grupa druga - frazeologizmy rodzime nieznane językowi ogólnopolskiemu - jest najliczniejsza, dlatego dominuje wśród związków posegregowanych frekwencyjnie. W pokoleniu III wyniki odnoszące się do związków charakterystycznych dla regionu są wyższe niż u młodszych pokoleń (np. bieda się hejbła).

5. Kalki i parafrazy to warstwa recesywna frazeologii, choć jej znajomość bierna nie jest niska w porównaniu z pozostałymi grupami. Istnieją przy tym także związki pochodzenia niemieckiego bardzo silnie zakorzenione w języku miejskim (jak np. popularne robić // zrobić łóżko, tapczan). Przykładem ekspansywności moga być tu też zwroty, które z gwary miejskiej Poznania przeszły do języka potocznego: nie mieć wszystkich $w$ domu (niem. nicht alle zu Hause haben) oraz trzymać pysk (niem. halt's Maul). Równocześnie, takie związki jak być $w$ druku z powodu zanikania wpływów niemieckich na

${ }^{22}$ Największą orientację $\mathrm{w}$ zasobach frazeologicznych odnotowano $\mathrm{u}$ badanych $\mathrm{z}$ wykształceniem podstawowym, najmniejszą - $\mathrm{u}$ ankietowanych $\mathrm{z}$ wykształceniem zawodowym. Pomiędzy tymi dwiema grupami uplasowali się respondenci z wykształceniem średnim lub wyższym. Liczba znanych frazeologizmów nie jest zatem wprost zależna od wykształcenia.

${ }^{23}$ Por. A. Piotrowicz, M. Witaszek-Samborska, Gwara poznańska w odczuciu poznaniaków, w: Synchroniczne i diachroniczne aspekty badań polszczyzny, t. 4, red. M. Białoskórska, Szczecin 1998, s. 193-201.

${ }^{24}$ D. Buttler, Polskie stownictwo potoczne. IV. Frazeologia, „Poradnik Językowy” 1978, z. 1, s. 12 .

${ }^{25}$ Ibidem, s. 7. 
gwarę tracą motywację i często odczytywane są dosłownie. Szczególnie, gdy tak jak w podanym przykładzie można skojarzyć je ze słownictwem ogólnym (tu: 'drukować się [o książce, gazecie]'). Na skutek braku bliższego kontaktu z językiem, z którego się wywodzą, związki stałe tracą swą obrazowość. Natomiast konstrukcje składniowe wycofują się z użycia z powodu swej nietypowości, wymykającej się regułom rządzącym polską składnią (co utrudnia dążenie języka do skrótowości i precyzji).

Frazeologia stanowi ciekawy, choć trochę niedoceniany fragment polskich zasobów leksykalnych. Obrazuja to przedstawione powyżej badania. W bardzo wielu przypadkach respondenci rozpoznawali poszczególne słowa składające się na związek, jednocześnie nie odczytując jego globalnego znaczenia. Przeszkodą w poprawnym formułowaniu odpowiedzi był dla wielu osób sam przedmiot badań. Okazuje się, że duży odsetek ankietowanych deklaruje znajomość czynną frazeologii, podając przy tym błędne definicje i określenia. W ten sposób część związków przechodzi różnego rodzaju modyfikacje semantyczne, które czasami mogą spowodować powstanie alternatywnej formy frazeologizmu zaaprobowanej przez uzus ${ }^{26}$. Niektóre pomyłki wynikają z trudności opisania danego zjawiska słowami innymi niż wyrażenie gwarowe. Prawdopodobnie z biegiem czasu frazeologizmy charakterystyczne dla gwary miejskiej Poznania szybciej wycofują się z użycia niż leksemy. Być może dzieje się tak pod wpływem ogólnopolskiego języka potocznego. Kilkanaście najpopularniejszych związków weszło zresztą do jego zasobów. Poza tym, głównie w tej odmianie języka frazeologizmy regionalne mają swoje odpowiedniki.

Gwara miejska ma pewne cechy wspólne z językiem potocznym. Obie te odmiany są kolokwialne i używane w kontaktach nieoficjalnych, a według Alfreda Zaręby ${ }^{27}$ można je uznać za różne przejawy języka miejskiego. Dlatego wykazują analogie, czego przykładem jest m.in. podobieństwo struktury formalnej oraz semantycznej wielkopolskiego słownictwa regionalnego do struktury słownictwa potocznego ${ }^{28}$. Dotyczy to również frazeologii ${ }^{29}$. Tak jak i w języku potocznym, w gwarze poznańskiej znajdziemy popularne zespoły

26 Odnotowałam wiele błędów oraz różnic w rozumieniu frazeologizmów, np. dostać sztycha często definiowane jest jako 'przeziębić się, zachorować' zamiast 'zepsuć się, skwaśnieć' (kolejno 14 i 13 odpowiedzi).

27 A. Zaręba, $O$ zakresie $i$ metodzie badań języka miast polskich, w: Miejska polszczyzna mówiona - metodologia badań. Materiaty z konferencji naukowej w Sosnowcu w dniach 20-21 czerwca 1974 roku, red. W. Lubaś, Katowice 1976, s. 35.

28 A. Piotrowicz, M. Witaszek-Samborska, Z doświadczeń badawczych nad gwarq miejska Poznania, w: Ad perpetuam rei memoriam. Profesorowi W.R. Rzepce z okazji 65. urodzin, red. J. Migdał, Poznań 2005, s. 329.

29 Wymieniam kilka najpopularniejszych za D. Buttler, op.cit., s. 7-19. 
frazeologizmów wyrażających to samo znaczenie. Przykładem są grupy o znaczeniu 'być pobitym, zbitym'30 (11 jednostek, np. dostać sypy, mieć nawszczylane), 'lekceważyć' (5 jednostek, np. haknij mnie // się w motykę, może mi skoczyć na wacka!), 'kraść' (2 jednostki: iść // chodzić na harendę // harynde oraz iść // chodzić na skibę), 'spać' (3 jednostki: być na śpiku, dusić garę, robić nyny, a także 2 o znaczeniu 'iść spać': iść (robić) nyny, iść na gare). Ponadto frazeologizmy potoczne często wyrażają procesy intelektualne i stany emocjonalne. Widoczne jest to w miejskiej gwarze Poznania: znaczenie 'zwariować, dostać bzika' reprezentuje 20 związków, 'być głupim, nienormalnym' - 15 związków, 'bać się' - 8 związków. Dwie najważniejsze cechy ogólnopolskiej leksyki potocznej (według Danuty Buttler), czyli antropocentryzm i orientacja szczegółowo-konkretna ${ }^{31}$, charakterystyczne są również dla frazeologizmów poznańskich.

Frazeologia, stanowiąc element językowego nazewnictwa, odbija życie społeczeństwa. Dlatego przechodzi wraz z nim przeobrażenia historyczne i kulturowe. Przykładem tego są takie związki, jak ciepty land, kampa góra!, radio Swarzędz, zupa butczanna, które obecnie nie są używane (lub nawet nie są znane - jak cieply land), ponieważ treści przez nie wyrażane nie mają zastosowania. Mogą to być przedmioty dziś rzadko spotykane (np. zupa bułczanna) lub określenia zjawisk należących już do historii (mimo że frazeologizm nie jest taki stary - np. radio Swarzędz). Być może na miejsce recesywnych jednostek pojawią się nowe, będące wyznacznikiem naszych czasów. Bardziej prawdopodobne jednak jest, że stanie się to w obrębie języka potocznego niż gwary miejskiej. Jest on bardziej ekspansywną odmianą niż gwara, o czym mogą świadczyć mylne skojarzenia niektórych regionalnych związków frazeologicznych z potocznymi, występujące zazwyczaj w pokoleniu najmłod$\mathrm{szym}^{32}$. Poza tym jako odmiana o szerszym zasięgu terytorialnym „,najszybciej odzwierciedla zmiany zachodzące w życiu narodu i w jego kulturze"33.

${ }^{30}$ U Danuty Buttler mowa o znaczeniu 'bić, pobić', ale jest to znaczenie pokrewne.

${ }^{31}$ Podaję za: A. Piotrowicz, M. Witaszek-Samborska, $Z$ doświadczeń badawczych..., s. 330 .

${ }^{32} \mathrm{Na}$ przykład frazeologizm lepsza nuta definiowany w grupie I jako 'lepsza/dobra piosenka, muzyka' zamiast jako 'prostytutka'.

${ }^{33}$ K. Ożóg, Ustna odmiana języka ogólnego, w: Wspótczesny język polski, red. J. Bartmiński, Lublin 2001, s. 87. 


\section{Marta Kołodziejczyk}

\section{The knowledge of the local phraseology among the inhabitants of Poznań}

The article discusses the issues related to the knowledge of the regional phraseology among present-day users of the local Poznan dialect. The research material is excerpted from a survey conducted among 120 local inhabitants within the age bracket of 15-87. Based on the results of the survey it is fair to conclude that the level of usage of the discussed phaseological units is highly dependent on the age of respondents, with the group of middle-aged people having the highest competence in the usage of dialectal forms. The most widely used expressions and phrases include those that describe the properties of human beings - physical and mental features and one's behaviour or activities. The examination of the collected material allows us to compare the frequency within particular groups of phraseologisms that can be distinguished in the local dialect. It turns out that the most stable word groups are those units that have their counterparts in standard Polish, whereas the least stable are loan translations and the paraphrases from the German language. The article also indicates the similarities between the semantic structure of the phrasological layer in Poznan dialect and the structure of Polish colloquial vocabulary. 